\title{
Faktor-Faktor Yang Memengaruhi Perilaku Menabung Di Kalangan Mahasiswa \\ (Studi Pada Mahasiswa Fakultas Ekonomi dan Bisnis di Universitas Muhammadiyah Purwokerto, Universitas Jendral Soedirman dan Universitas Wijaya Kusuma)
}

\author{
Ayu Ramadhaning Tyas ${ }^{(1)}$ \\ Program Studi Manajemen S1 \\ Fakultas Ekonomi dan Bisnis Universitas Muhammadiyah Purwokerto ${ }^{(1)}$ \\ Email: 'ayuramadhaningtyas@gmail.com \\ Ika Yustina Rahmawati ${ }^{(2)}$ \\ Program Studi Manajemen S1 \\ Fakultas Ekonomi dan Bisnis Universitas Muhammadiyah Purwokerto ${ }^{(2)}$ \\ Email : ${ }^{2}$ rahmawatirahma2015@gmail.com
}

\begin{abstract}
ABSTRAK
Penelitian ini bertujuan untuk menguji pengaruh sosialisasi orang tua, melek finansial, teman sebaya dan kontrol diri terhadap perilaku menabung. Penelitian ini merupakan penelitian kuantitatif dengan menggunakan kuesioner sejumlah 325 responden kepada mahasiswa di Purwokerto. Subyek dalam penelitian ini adalah Mahasiswa Fakultas Ekonomi dan Bisnis di Universitas Muhammadiyah Purwokerto, Universitas Jendral Soedirman dan Universitas Wijaya Kusuma. Teknik pengambilan sampel menggunakan metode convenience sampling. Analisis data menggunakan uji regresi linier berganda menggunakan data ordinal. Dari hasil penelitian menunjukkan bahwa sosialisasi orang tua, melek finansial, teman sebaya dan kontrol diri berpengaruh positif dan signifikan terhadap perilaku menabung.

Kata kunci : Sosialisasi Orang Tua, Melek Finansial, Teman Sebaya, Kontrol Diri, Perilaku Menabung
\end{abstract}

\begin{abstract}
This study aims to examine the influence of parental socialization, financial literacy, peer pressure and self-control on saving behavior. This research is a quantitative study using a questionnaire of 325 respondents to students in Purwokerto. The subjects in this study were students of the Faculty of Economics and Business at the University of Muhammadiyah Purwokerto, University Jendral Soedirman and University Wijaya Kusuma. The sampling technique used a convenience sampling method. Data analysis used multiple linear regression test using ordinal data. The results showed that parental socialization, financial literacy, peers and self-control had a positive and significant effect on saving behavior.
\end{abstract}

Keywords: Parental Socialization, Financial Literacy, Peers, Self Control, Saving Behavior

\section{PENDAHULUAN}

Menabung merupakan hal yang tak asing lagi dalam masyarakat Indonesia. Menabung adalah menyisihkan sebagian uang yang dimiliki untuk disimpan. Menabung ialah salah satu cara dalam mengelola keuangan untuk mencapai keinginan seseorang. Menurut Kamus Besar Bahasa Indonesia menabung tersebut berasal dari kata dasar yakni tabung. Menabung itu memiliki arti kedalam golongan atau kelas kata kerja sehingga menabung bisa menyatakan sebuah tindakan, keberadaan, pengalaman, atau pengertian dinamis lainnya. Perkembangan menabung di masyarakat Indonesia sedang mengalami 
peningkatan dibuktikan dengan data dari Bank Indonesia (BI) bahwa adanya akselerasi pertumbuhan dana pihak ketiga (DPK) pada Juli 2018. Pertumbuhan ini khususnya terjadi pada instrumen tabungan dan simpanan berjangka. Bank sentral mencatat, penghimpunan DPK pada Juli 2018 sebesar Rp 5.209 triliun. Angka ini tumbuh 6,4 persen secara tahunan, sedikit lebih tinggi dibandingkan pertumbuhan pada bulan sebelumnya. Selain itu, bank sentral melaporkan pula peningkatan pertumbuhan DPK terjadi lantaran adanya peningkatan proporsi pendapatan konsumen yang digunakan sebagai simpanan.

Mahasiswa di Purwokerto berasal dari berbagai kota di Indonesia sehingga sebagian besar merupakan mahasiswa rantau atau tidak tinggal dengan orang tua mereka. Permasalahan yang dialami mahasiswa umumnya adalah belum memiliki pendapatan dan cadangan dana yang terbatas. Mahasiswa yang tidak tinggal dengan orang tuanya harus belajar mandiri secara finansial dan bertanggung jawab atas keputusan yang mereka buat. Pada dasarnya orang tua telah memperkirakan kebutuhan mereka selama satu minggu. Namun, yang terjadi umumnya adalah dana mereka habis sebelum tanggal kiriman datang. Hal tersebut terjadi karena pengelolaan keuangan yang kurang baik dan adanya kebutuhan yang mendesak.

Sebagian besar mahasiswa merupakan mahasiswa rantauan yang jauh dari orang tua, dalam memenuhi kebutuhan hidup salalu menunggu kiriman uang saku dari orang tua, apabila tidak pandai mengatur keuangannya, dana yang disiapkan untuk seminggu bisa habis dalam waktu beberapa hari. Serta ada juga mahasiswa yang mampu mengelola keuangannya dengan baik, bahkan bisa menyisikan uang tersebut untuk ditabung. Perilaku menabung di kalangan mahasiswa terbilang cukup karena hampir semua mahasiswa memiliki rekening tabungan di bank selain itu mahasiswa juga dapat menyimpan sebagian uang mereka dicelengan yang mereka buat sendiri.

Dalam hal ini menabung dapat menjadi sebuah alternatif bagi seseorang dalam menyimpan uang mereka. Menabung dapat dijadikan sebuah investasi bagi kebayakan masyarakat pada saat ini mengingat kebutuhan yang beragam dari setiap orang. Menabung juga penting untuk kesejahteraan di kehidupan mendatang apabila sudah tidak dapat bekerja, tidak mendapatkan penghasilan lagi, serta menabung dapat melatih diri untuk bersikap hemat dan mandiri. Hal ini dapat berpengaruh dalam waktu yang lama, apabila seseorang tidak mempunyai tabungan maka tidak ada cadangan dana yang digunakan untuk memenuhi kebutuhan yang bersifat darurat, sehingga akan menimbulkan ketergantungan kepada orang lain (Tunggal Purnama Putri dan Susanti, 2018).

Menurut Sirine dan Utami (2016) perilaku menabung dipengaruhi oleh 4 (empat) faktor yaitu, sosialisasi orang tua, melek finansial, teman sebaya dan kontrol diri. Pertama, Orang tua memiliki peran terhadap anaknya dalam memberikan pendidikan tentang keuangan dalam keluarga. Sosialisasi orang tua tentang dampak positif menabung dan pentingnya membudayakan perilaku menabung menjadi faktor penunjang perilaku anak dalam keputusan investasi dan konsumsi mereka. Hasil penelitian ini didukung oleh penelitian yang dilakukan oleh Sirine dan Utami (2016) yang menunjukkan bahwa sosialisasi orang tua secara parsial dan simultan berpengaruh positif signifikan terhadap perilaku menabung. Selanjutnya penelitian yang dilakukan oleh penelitian dari Marwati (2018), Putra (2018) Ardiana (2016) Amilia, dkk (2018), yang menjelaskan bahwa variabel sosialisasi orang tua berpengaruh positif signifikan terhadap perilaku menabung dan manajemen keuangan pribadi.

Kedua, Melek finansial merupakan faktor penting dalam menentukan perilaku menabung dan masalah keuangan. Hasil penelitian ini didukung oleh penelitian yang dilakukan oleh Sirine dan Utami (2016), yang menunjukkan bahwa melek finansial berpengaruh positif signifikan terhadap perilaku menabung di kalangan mahasiswa. Selanjutnya penelitian yang dilakukan oleh Ulfi, dkk (2017), Marwati (2018), Amilia, 
dkk (2018) Lestari dan Trenggana (2017) Putri dan Susanti (2018), yang menunjukkan bahwa melek finansial berpengaruh positif signifikan terhadap perilaku menabung. Sedangkan Dewi, dkk (2017), Arianti (2018) yang menunjukkan bahwa melek finansial berpengaruh negatif signifikan terhadap perilaku menabung

Ketiga, Teman Sebaya memegang peranan penting ketiga dalam perilaku menabung seseorang. Teman sebaya berperan sebagai agen sosialisasi yang membantu membentuk perilaku dan keyakinan anak. Hasil penelitian yang dilakukan oleh Sirine dan Utami (2016) yang menunjukkan bahwa teman sebaya tidak berpengaruh positif signifikan terhadap perilaku menabung di kalangan mahasiswa. Sedangkan penelitian yang dilakukan oleh Ulfi, dkk (2017), Dewi, dkk (2017), Marwati (2018) menjelaskan terdapat hubungan positif dan signifikan perilaku teman sebaya dengan kebiasaan menabung dan perilaku komsumtif. Amilia, dkk (2018), Chotimah dan Rohayati (2015) menjelaskan variabel teman sebaya berpengaruh positif signifikan terhadap perilaku menabung dan manajemen keuangan pribadi.

Keempat, Kontrol diri merupakan hal yang penting sebelum individu memutuskan untuk mengambil keputusan dalam berperilaku. Ketika individu mempunyai kontrol diri yang baik, maka akan mengendalikan penggunaan uangnya dan dapat melakukan pengelolaan keuangan dengan lebih baik dan mempunyai niat untuk menabung (Tunggal Purnama Putri, 2018). Hasil penelitian ini didukung oleh penelitian yang dilakukan oleh Sirine dan Utami (2016) Ardiana (2016) yang menunjukkan bahwa kontrol diri berpengaruh positif signifikan terhadap perilaku menabung di kalangan mahasiswa. Selanjutnya penelitian yang dilakukan oleh Marwati (2018), Putri (2018) menunjukkan bahwa kontrol diri berpengaruh positif signifikan terhadap perilaku menabung.

\section{Rumusan Masalah}

Berdasarkan latar belakang di atas, maka rumusan masalah dalam penelitian ini adalah sebagai berikut:

1. Apakah sosialisasi orang tua, melek finansial, teman sebaya dan kontrol diri secara simultan berpengaruh signifikan terhadap perilaku menabung pada mahasiswa Fakultas Ekonomi di Purwokerto?

2. Apakah sosialisasi orang tua berpengaruh positif signifikan terhadap perilaku menabung pada mahasiswa Fakultas Ekonomi di Purwokerto?

3. Apakah melek finansial berpengaruh positif signifikan terhadap perilaku menabung mahasiswa Fakultas Ekonomi di Purwokerto?

4. Apakah teman sebaya berpengaruh positif signifikan terhadap perilaku menabung pada mahasiswa Fakultas Ekonomi di Purwokerto?

5. Apakah kontrol diri berpengaruh positif signifikan terhadap perilaku menabung pada mahasiswa Fakultas Ekonomi di Purwokerto?

\section{TINJAUAN PUSTAKA}

\section{Perilaku Menabung}

Perilaku menabung adalah tindakan nyata yang dipengaruhi faktor-faktor kejiwaan dan faktor lain yang mengarahkan mereka untuk menyisihkan pendapatannya, serta menggunakan jasa perbankan untuk sarana menabung Perilaku menabung adalah kombinasi dari persepsi kebutuhan masa depan, keputusan menabung dan tindakan penghematan.

Menurut Triani (2017) dalam Suri Amilia (2018) terdapat 7 indikator mengenai perilaku menabung :

1. Menabung secara periodik. 
2. Membandingkan harga sebelum melakukan pembelian.

3. Mengontrol pengeluaran.

4. Memiliki uang cadangan.

5. Berhemat

6. Menabung terlebih dahulu untuk rencana di masa yang akan datang.

7. Membeli barang yang dibutuhkan saja.

\section{Sosialisasi Orang Tua}

Sosialisasi orang tua merupakan proses belajar mengenai nilai-nilai dan normanorma, kebiasaan, sikap dan tingkah laku yang berlaku di dalam masyarakat yang dipelajari melalui orang tua sebagai media sosialisasinya. Keluarga merupakan tempat yang paling dominan dalam proses sosialisasi anak tentang masalah keuangan. Proses pendidikan yang meliputi mental, fisik dan intelektual di lingkungan keluarga dapat berlangsung terus hingga anak dewasa (Suri Amilia, 2018).

Menurut Suri Amilia (2018), indikator sosialisasi orang tua, yaitu:

1. Mendorong cara mengelola uang yang benar.

2. Mengenalkan uang pada anak.

3. Diskusi tentang cara mengelola uang yang tepat.

4. Pengalaman.

\section{Melek Finansial}

Melek finansial merupakan faktor penting dalam menentukan perilaku menabung dan masalah keuangan. Penelitian Delafrooz dan Laily (2011) dengan sampel karyawan di sektor publik dan swasta menunjukkan bahwa individu yang tingkat melek finansialnya rendah tidak mudah untuk menabung dan akhirnya mengalami masalah keuangan di masa depan.

Menurut Suri Amilia (2018) indikator literasi keuangan antara lain:

1. Pengetahuan umum tentang keuangan

2. Simpanan dan pinjaman

3. Asuransi

4. Investasi.

\section{Teman Sebaya}

Teman sebaya adalah anak-anak atau remaja yang memiliki usia dan tingkat kedewasaan yang kurang lebih sama. Mahasiswa termasuk sebagai kategori masa remaja akhir yaitu antara usia 18 sampai 25 tahun. Pada tahap ini perkembangan intelektual remaja telah berada pada taraf operasional formal, sehingga kemampuan nalarnya tinggi dan lebih matang dalam hal mengambil keputusan termasuk tindakan ekonomi.

Menurut Suri Amilia (2018) menjelaskan 5 indikator teman sebaya :

1. Menabung secara teratur

2. Pengelolaan keuangan

3. Perbandingan pendapatan dan pengeluaran

4. Banyak waktu luang

5. Pengeluaran rutin

\section{Kontrol Diri}

Kontrol diri merupakan hal yang penting sebelum individu memutuskan untuk mengambil keputusan dalam berperilaku. Ketika individu mempunyai kontrol diri yang baik, maka akan mengendalikan penggunaan uangnya dan dapat melakukan pengelolaan 
keuangan dengan lebih baik dan mempunyai niat untuk menabung (Tunggal Purnama Putri, 2018).

Menurut Suri Amilia (2018) indikator pengendalian diri yaitu :

1. Perilaku hidup boros tidak sesuai dengan norma dan etika.

2. Memilih/membeli suatu barang atau jasa sesuai dengan kebutuhan.

3. Konsumsi barang dan jasa sesuai dengan perencanaan anggaran pengeluaran.

4. Menghemat uang.

5. Tingkat pengeluaran diusahakan lebih kecil dari tingkat pendapatan.

\section{KERANGKA PEMIKIRAN}

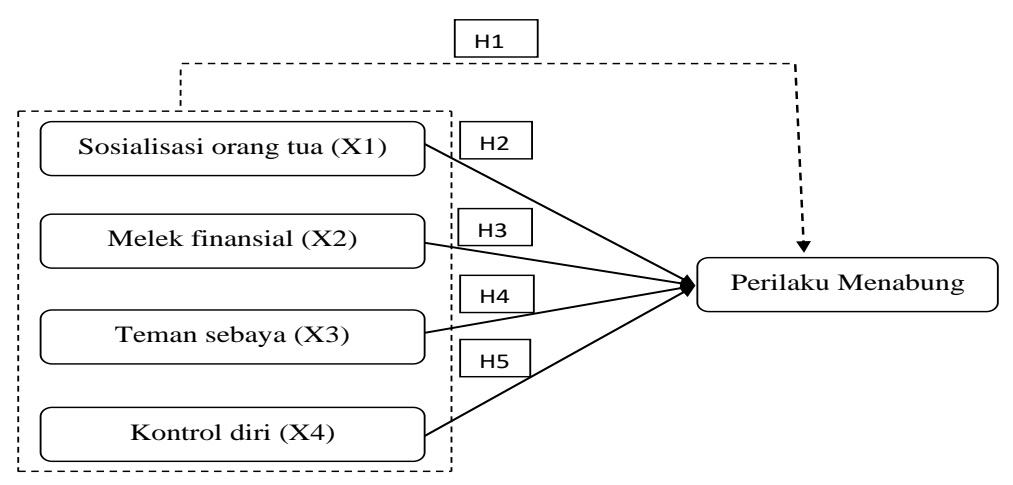

Keterangan garis :

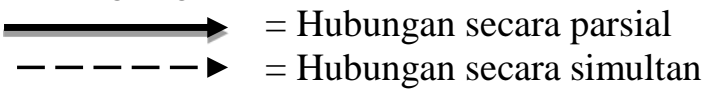

\section{METODE PENELITIAN}

Penelitian ini menggunakan pendekatan kuantitatif yang bertujuan untuk mengetahui pengaruh variabel independen terhadap variabel dependen. Dalam penelitian ini populasi yang digunakan adalah para mahasiswa yang sudah mengambil mata kuliah manajemen keuangan di Fakultas Ekonomi dan Bisnis Universitas Muhammadiyah Purwokerto, Fakultas Ekonomi dan Bisnis Universitas Jendral Soedirman, Fakultas Ekonomika dan Bisnis Universitas Wijaya Kusuma, berusia di atas 18-25 tahun dan memiliki tabungan berupa celengan atau rekening tabungan di Bank. Untuk menentukan ukuran sampel, penelitian ini menggunakan rumus dari Slovin untuk menghitung besarnya sampel (Suliyanto,2018;226) Sampel pada penelitian ini berjumlah 325 mahasiswa Fakultas Ekonomi di Purwokerto. Metode pengumpulan data penelitian ini dengan menggunakan kuesioner.

\section{HASIL DAN PEMBAHASAN}

\section{Uji Validitas}

Uji validitas digunakan untuk mengukur sah atau valid tidaknya suatu kuesioner. Suatu kuesioner dinyatakan valid jika pertanyaan pada kuesioner mampu mengungkapkan sesuatu yang akan diukur oleh kuesioner tersebut (Ghozali, 2018: 52). Pada penelitian ini diperoleh hasil bahwa nilai $r$ hitung seluruh item pernyataan lebih besar daripada $r$ tabel $(0,108471)$. Berdasarkan hasil uji validitas didapat semua variabel nilai $r$ hitung $>r$ tabel, Hasil pengujian tersebut menunjukkan instrumen penelitian variabel valid. 


\section{Uji Reliabilitas}

Menurut Ghozali (2016) reliabilitas sebenarnya adalah alat untuk mengukur suatu kuesioner yang merupakan indikator dari variabel atau konstruk. Menurut Ghozali (2016) jawaban responden terhadap pertanyaan ini di katakan reliabel jika.memberikan nilai Cronbach Alpha $>0.70$.

Tabel 1.5 Hasil Uji Reliabilitas

\begin{tabular}{|l|c|c|c|}
\hline \multicolumn{1}{|c|}{ Variabel } & Cronbanch's Alpha & Reliable & Keterangan \\
\hline Perilaku menabung & 0,729 & 0,70 & Reliabel \\
\hline Sosialisasi orang tua & 0,721 & 0,70 & Reliabel \\
\hline Melek finansial & 0,795 & 0,70 & Reliabel \\
\hline Teman sebaya & 0,702 & 0,70 & Reliabel \\
\hline Pengandalian diri & 0,728 & 0,70 & Reliabel \\
\hline & & & \\
\hline
\end{tabular}

Berdasar uji reliabilitas, nilai Cronbach's Alpha masing-masing variabel lebih besar dari 0,70 yang menunjukkan bahwa indikator-indikator yang digunakan dalam pernyataan kuisioner disetiap variabel dikatakan reliabel.

\section{UJI ASUMSI KLASIK}

\section{Uji Normalitas}

Uji normalitas bertujuan untuk menguji apakah dalam model regresi, variabel pengganggu atau residual memiliki distribusi normal. Uji statistik yang akan di gunakan yaitu uji statistik non-parametrik Kolmogorov-Smirnov (K-S). Jika signifikan > 0,05 maka variabel berdistribusi normal.

Tabel : 1.6 Uji Normalitas

\section{One-Sample Kolmogorov-Smirnov Test}

\begin{tabular}{|l|l|r|}
\hline \multicolumn{2}{|l|}{} & Unstandardized Residual \\
\hline $\mathrm{N}$ & Mean & 325 \\
\cline { 2 - 3 } Normal Parameters & Stb & $0 \mathrm{E}-7$ \\
\hline \multirow{3}{*}{ Most Extreme Differences } & Absolute & .27023650 \\
\cline { 2 - 3 } & Positive & .061 \\
\cline { 2 - 3 } & Negative & .058 \\
\hline Kolmogorov-Smirnov Z & -.061 \\
\hline \multicolumn{2}{|l|}{ Asymp. Sig. (2-tailed) } & 1.100 \\
\hline
\end{tabular}

a. Test distribution is Normal.

b. Calculated from data.

Berdasarkan pada hasil output SPSS uji Kolmogrov Smirnov di atas, nilai Asymp. Sig sebesar 0,178, nilai tersebut memenuhi ketentuan sig. (p) > 0,05 (level of signification). Hal ini berarti bahwa data residual berdistribusi normal.

\section{Uji Multikolinieritas}

Uji Multikolinearitas bertujuan untuk menguji apakah model regresi ditemukan adanya korelasi antar variabel bebas Ghozali (2016). Nilai cut off yang umum dipakai untuk menunjukan adanya multikolinearitas adalah nilai Tolerance $<0.10$ atau sama dengan nilai $V I F>10$. 
Tabel 1.7 Hasil Uji Multikolinieritas

Coefficients $^{\mathrm{a}}$

\begin{tabular}{|c|c|c|c|c|c|c|c|c|}
\hline \multirow{2}{*}{\multicolumn{2}{|c|}{ Model }} & \multicolumn{2}{|c|}{$\begin{array}{c}\text { Unstandardized } \\
\text { Coefficients }\end{array}$} & \multirow{2}{*}{$\begin{array}{l}\text { Standardized } \\
\text { Coefficients }\end{array}$} & \multirow[t]{2}{*}{$\mathrm{T}$} & \multirow[t]{2}{*}{ Sig. } & \multicolumn{2}{|c|}{$\begin{array}{l}\text { Collinearity } \\
\text { Statistics }\end{array}$} \\
\hline & & B & $\begin{array}{l}\text { Std. } \\
\text { Error }\end{array}$ & & & & $\begin{array}{c}\text { Toleran } \\
\text { ce }\end{array}$ & VIF \\
\hline \multirow{5}{*}{1} & (Constant) & 1.273 & .216 & & 5.884 & .000 & & \\
\hline & $\begin{array}{l}\text { Sosialisasi } \\
\text { orang tua }\end{array}$ & .236 & .039 & .298 & 5.985 & .000 & .831 & 1.203 \\
\hline & \begin{tabular}{|l|} 
Melek \\
finansial
\end{tabular} & .174 & .041 & .206 & 4.263 & .000 & .885 & 1.130 \\
\hline & $\begin{array}{l}\text { Teman } \\
\text { sebaya }\end{array}$ & .110 & .037 & .149 & 2.953 & .003 & .813 & 1.230 \\
\hline & Kontrol diri & .174 & .043 & .200 & 4.059 & .000 & .845 & 1.183 \\
\hline
\end{tabular}

a. Dependent Variable: Perilaku Menabung

Pada tabel 4.9 diatas menunjukkan bahwa nilai tolerance masing-masing variabel tidak ada yang dibawah 0,10. Begitu juga dengan nilai VIF ketiga variabel dibawah 10. Berdasarkan data tersebut maka penelitian ini bebas dari asumsi multikolinieritas.

\section{Uji Heterokedastisitas}

Uji Heteroskedastisitas bertujuan menguji apakah dalam model regresi terjadi ketidaksamaan variance dari residual satu pengamatan ke pengamatan yang lain (Ghozali, 2016). Masalah heterokedastisitas dalam model persamaan regresi ini dilakukan dengan metode Glejser Test, yaitu dengan cara meregresikan nilai absolute residual terhadap variabel independen, sehingga dapat diketahui ada tidaknya derajat kepercayaan 5\%.

Tabel 1.8 Hasil Uji Hetereokedastisitas

Coefficients $^{\mathrm{a}}$

\begin{tabular}{|c|c|c|c|c|c|c|}
\hline \multirow{2}{*}{\multicolumn{2}{|c|}{ Model }} & \multicolumn{2}{|c|}{$\begin{array}{c}\text { Unstandardized } \\
\text { Coefficients }\end{array}$} & \multirow{2}{*}{$\begin{array}{c}\begin{array}{c}\text { Standardized } \\
\text { Coefficients }\end{array} \\
\text { Beta } \\
\end{array}$} & \multirow[t]{2}{*}{$\mathrm{T}$} & \multirow[t]{2}{*}{ Sig. } \\
\hline & & $\mathrm{B}$ & Std. Error & & & \\
\hline \multirow{5}{*}{1} & (Constant) & .460 & .145 & & 3.170 & .002 \\
\hline & $\begin{array}{l}\text { Sosialisasi orang } \\
\text { tua }\end{array}$ & -.043 & .026 & -.099 & -1.634 & .103 \\
\hline & Melek finansial & .013 & .027 & .027 & .460 & .646 \\
\hline & Teman sebaya & -.025 & .025 & -.062 & -1.018 & .310 \\
\hline & Kontrol diri & -.011 & .029 & -.024 & -.390 & .696 \\
\hline
\end{tabular}

a. Dependent Variable: Abs

Nilai sig dari masing-masing variabel lebih $>0,05$ dapat disimpulkan data dari penelitian ini terbebas dari gejala heteroskedastisitas.

\section{UJI ANALISIS DATA}

\section{Uji Regresi Linier Berganda}

Analisa regresi berganda digunakan untuk menganalisa pengaruh beberapa variabel bebas terhadap variabel terikat secara bersama-sama. 
Tabel : 1.9 Uji Regresi Linier Berganda

Coefficients $^{\mathrm{a}}$

\begin{tabular}{|c|c|c|c|c|c|c|}
\hline \multirow{2}{*}{\multicolumn{2}{|c|}{ Model }} & \multicolumn{2}{|c|}{$\begin{array}{l}\text { Unstandardized } \\
\text { Coefficients }\end{array}$} & \multirow{2}{*}{$\begin{array}{c}\begin{array}{c}\text { Standardized } \\
\text { Coefficients }\end{array} \\
\text { Beta }\end{array}$} & \multirow[t]{2}{*}{$\mathrm{t}$} & \multirow[t]{2}{*}{ Sig. } \\
\hline & & B & $\begin{array}{l}\text { Std. } \\
\text { Error }\end{array}$ & & & \\
\hline \multirow{5}{*}{1} & (Constant) & 1.273 & .216 & & 5.884 & .000 \\
\hline & $\begin{array}{l}\text { Sosialisasi orang } \\
\text { tua }\end{array}$ & .236 & .039 & .298 & 5.985 & .000 \\
\hline & Melek finansial & .174 & .041 & .206 & 4.263 & .000 \\
\hline & Teman sebaya & .110 & .037 & .149 & 2.953 & .003 \\
\hline & Kontrol diri & .174 & .043 & .200 & 4.059 & .000 \\
\hline
\end{tabular}

a. Dependent Variable: Perilaku Menabung

Berdasarkan hasil analisis regresi tersebut di atas, dapat disusun persamaan regresi sebagai berikut:

$\mathrm{Y}=\alpha+\beta_{1} \mathrm{X}_{1}+\beta_{2} \mathrm{X}_{2}+\beta_{3} \mathrm{X}_{3}+\beta_{4} \mathrm{X}_{4}+e$

$\mathrm{Y}=1,273+0,236 \mathrm{X}_{1}+0,174 \mathrm{X}_{2}+0,110 \mathrm{X}_{3}+0,174 \mathrm{X}_{4}$

Persamaan regresi tersebut diatas dapat dijelaskan sebagai berikut:

$\alpha=1,273$, nilai konstanta sebesar 1,273 satuan yang artinya jika sosialisasi orang tua, melek finansial, teman sebaya, dan kontrol diri tidak ada perubahan, maka perilaku menabung sebesar 1,273 satuan

$\mathrm{b} 1=0,236$, artinya koefisien sosialisasi orang tua naik sebesar satu satuan 0,236 berarti perilaku menabung akan mengalami peningkatan sebesar 0,236 satuan apabila variabel lain tetap.

$\mathrm{b} 2=0,174$, artinya koefisien melek finansial naik sebesar satu satuan 0,174 berarti perilaku menabung akan mengalami peningkatan sebesar 0,174 satuan apabila variabel lain tetap.

b3 $=0,110$, artinya koefisien teman sebaya naik sebesar satu satuan 0,110 berarti perilaku menabung akan mengalami peningkatan sebesar 0,110 satuan apabila variabel lain tetap.

$\mathrm{b} 4=0,174$ artinya koefisien kontrol diri naik sebesar satu satuan 0,174 berarti perilaku menabung akan mengalami peningkatan sebesar 0,174 satuan apabila variabel lain tetap.

\section{Koeisien Determinasi}

Koefisien determinasi (Adjusted $R_{2}$ ) digunakan untuk mengukur seberapa jauh kemampuan model dalam menerangkan variasi variabel dependen.

Tabel 1.10 Hasil Nilai Koefisien Determinasi

Model Summary

\begin{tabular}{|l|r|r|r|r|}
\hline Model & \multicolumn{1}{|c|}{$\mathrm{R}$} & $\mathrm{R}$ Square & $\begin{array}{c}\text { Adjusted R } \\
\text { Square }\end{array}$ & $\begin{array}{c}\text { Std. Error of } \\
\text { the Estimate }\end{array}$ \\
\hline 1 & $.585^{\mathrm{a}}$ & .342 & .334 & .27192 \\
\hline
\end{tabular}

a. Predictors: (Constant), Sosialisasi Orang Tua, Melek

Finansial Teman Sebaya, Kontrol Diri

Berdasarkan tabel 1.10 di atas dapat diketahui nilai Adjusted $R$ Squaredari model regresi yang terbentuk dalam penelitian ini adalah sebesar 0,334 yang menunjukkan 
kemampuan variabel independen (sosialisasi orang tua, melek finansial, teman sebaya dan kontrol diri) dalam menjelaskan variabel dependen (perilaku menabung) adalah sebesar $33,4 \%$, sisanya sebesar $66,6 \%$ dijelaskan oleh variabel lain yang tidak termasuk dalam model.

\section{UJI HIPOTESIS}

\section{Uji F}

Pengujian hipotesis dengan uji $\mathrm{F}$ (Simultan) dalam penelitian ini menyatakan bahwa sosialisasi keuangan, melek finansial, teman sebaya dan kontrol diri, berpengaruh signifikan terhadap perilaku menabung.

Tabel 1.11 Uji F

\begin{tabular}{|c|c|c|c|c|c|c|}
\hline \multicolumn{7}{|c|}{ ANOVA $^{a}$} \\
\hline & & Sum of & $\mathrm{df}$ & Mean Square & $\mathrm{F}$ & Sig. \\
\hline \multirow{3}{*}{1} & Regression & 12.307 & 4 & 3.077 & 41.609 & $.000^{\mathrm{b}}$ \\
\hline & Residual & 23.661 & 320 & .074 & & \\
\hline & Total & 35.968 & 324 & & & \\
\hline
\end{tabular}

a. Dependent Variable: Perilaku Menabung

b. Predictors: (Constant), Sosialisasi Orang Tua, Melek Finansial, Teman Sebaya, Kontrol Diri

Hipotesis pertama dilakukan untuk menguji apakah sosialisasi orang tua, melek finansial, teman sebaya, kontrol diri berpengaruh secara simultan terhadap perilaku menabung berdasarkan hasil tabel 4.24 nilai $F_{\text {hitung }}$ adalah sebesar 41,609 sedangkan $F_{\text {tabel }}$ sebesar 2,242201 df $1=(\mathrm{K}-1) 4-1=3$ dan df $2=(\mathrm{N}-\mathrm{K}-1) 325-4-1=320$. Selain itu nilai signifikasinya sebesar 0,000 lebih kecil dari pada taraf signifikasinya 0,05 . Karena $F$ hitung $>F_{\text {tabel }}$ dan nilai signifikasinya lebih kecil dari pada taraf signifikasi $(0,000<0,05)$, maka hipotesis pertama diterima, artinya sosialisasi orang tua, melek finansial, teman sebaya dan kontrol diri secara simultan berpengaruh signifikan terhadap perilaku menabung.

Uji T

Uji T digunakan untuk menguji apakah variabel independen berpengaruh secara parsial terhadap variabel dependen.

Tabel 1.12 Uji Regresi Linier Berganda

Coefficients $^{\mathrm{a}}$

\begin{tabular}{|c|c|c|c|c|c|c|}
\hline \multirow{2}{*}{\multicolumn{2}{|c|}{ Model }} & \multicolumn{2}{|c|}{$\begin{array}{c}\text { Unstandardized } \\
\text { Coefficients }\end{array}$} & \multirow{2}{*}{$\begin{array}{c}\text { Standardized } \\
\text { Coefficients } \\
\text { Beta } \\
\end{array}$} & \multirow[t]{2}{*}{$\mathrm{t}$} & \multirow[t]{2}{*}{ Sig. } \\
\hline & & $\mathrm{B}$ & Std. Error & & & \\
\hline \multirow{5}{*}{1} & (Constant) & 1.273 & .216 & & 5.884 & .000 \\
\hline & $\begin{array}{l}\text { Sosialisasi Orang } \\
\text { Tua }\end{array}$ & .236 & .039 & 298 & 5.985 & .000 \\
\hline & Melek Finansial & .174 & .041 & .206 & 4.263 & .000 \\
\hline & Teman Sebaya & .110 & .037 & .149 & 2.953 & .003 \\
\hline & Kntrol Diri & .174 & .043 & .200 & 4.059 & .000 \\
\hline
\end{tabular}

a. Dependent Variable: Perilaku Menabung 
1) Hipotesis kedua dilakukan untuk menguji apakah sosialisasi orang tua berpengaruh dan signifikan terhadap perilaku menabung, variabel sosialisasi orang tua memiliki nilai $t_{\text {hitung }}$ sebesar 5,985 sedangkan $t_{\text {tabel }}$ sebesar 1,967 sedangkan nilai signifikan sebesar 0,000 kurang dari 0,05 . Oleh karena nilai $t_{\text {hitung }}>t_{\text {tabel }}(5,985>1,967)$ artinya secara parsial ada pengaruh positif signifikan antara sosialisasi orang tua terhadap perilaku menabung, sehingga Ha diterima dan Ho ditolak.

2) Hipotesisi ketiga dilakukan untuk menguji apakah melek finansial berpengaruh dan signifikan terhadap perilaku menabung, variabel melek finansial memiliki nilai $t_{\text {hitung }}$ sebesar 4,263 sedangkan $t_{\text {tabel }}$ sebesar 1,967 sedangkan nilai signifikan sebesar 0,000 kurang dari 0,05 . Oleh karena nilai $t_{\text {hitung }}>t_{\text {tabel }}(4,263>1,967)$ artinya secara parsial ada pengaruh positif signifikan antara melek finansial terhadap perilaku menabung, sehingga Ha diterima dan Ho ditolak.

3) Hipotesis keempat dilakukan untuk menguji apakah teman sebaya berpengaruh dan signifikan terhadap perilaku menabung, variabel teman sebaya memiliki nilai $t_{\text {hitung }}$ sebesar 2,953 sedangkan $t_{\text {tabel }}$ sebesar 1,967 sedangkan nilai signifikan sebesar 0,003 kurang dari 0,05 . Oleh karena nilai $t_{\text {hitung }}>t_{\text {tabel }}(2,037>1,967)$ artinya secara parsial ada pengaruh positif signifikan antara teman sebaya terhadap perilaku menabung, sehingga Ha diterima dan Ho ditolak.

4) Hipotesisi kedua dilakukan untuk menguji apakah kontrol diri berpengaruh dan signifikan terhadap perilaku menabung, variabel kontrol diri memiliki nilai $t_{\text {hitung }}$ sebesar 4,059 sedangkan $t_{\text {tabel }}$ sebesar 1,967 sedangkan nilai signifikan sebesar 0,000 kurang dari 0,05 . Oleh karena nilai $t_{\text {hitung }}>t_{\text {tabel }}(4,059>1,967)$ artinya secara parsial ada pengaruh positif signifikan antara kontrol diri terhadap perilaku menabung, sehingga Ha diterima dan Ho ditolak.

\section{KESIMPULAN}

Berdasarkan analisis data dan pembahasan yang telah dilakukan maka dapat ditarik kesimpulan sebagai berikut:

1. Sosialisasi orang tua, melek finansial, teman sebaya dan kontrol diri secara simultan berpengaruh positif signifikan terhadap perilaku menabung mahasiswa Fakultas Ekonomi dan Bisnis di Universitas Muhammadiyah Purwokerto, Universitas Jendral Soedirman dan Universitas Wijaya Kusuma.

2. Sosialisasi orang tua berpengaruh positif signifikan terhadap perilaku menabung mahasiswa Fakultas Ekonomi dan Bisnis di Universitas Muhammadiyah Purwokerto, Universitas Jendral Soedirman dan Universitas Wijaya Kusuma.

3. Melek finansial berpengaruh positif signifikan terhadap perilaku menabung mahasiswa Fakultas Ekonomi dan Bisnis di Universitas Muhammadiyah Purwokerto, Universitas Jendral Soedirman dan Universitas Wijaya Kusuma.

4. Teman sebaya berpengaruh positif signifikan terhadap perilaku menabung mahasiswa Fakultas Ekonomi dan Bisnis di Universitas Muhammadiyah Purwokerto, Universitas Jendral Soedirman dan Universitas Wijaya Kusuma.

5. Kontrol diri berpengaruh positif signifikan terhadap perilaku menabung mahasiswa Fakultas Ekonomi dan Bisnis di Universitas Muhammadiyah Purwokerto, Universitas Jendral Soedirman dan Universitas Wijaya Kusuma.

\section{SARAN}

Berdasarkan penulisan penelitian ini, peneliti menyadari masih terdapat banyak kekurangan didalamnya. Saran dari peneliti adalah sebagai berikut: 
1. Peneltian selanjutnya diharapkan dapat menambahkan beberapa variabel lain yang dapat mempengaruhi perilaku menabung seperti tingkat pendidikan, pendapatan, jenis pekerjaan, dan lain-lain.

2. Peneltian selanjutnya hendaknya melakukan kembali penelitian terkait pengaruh variabel teman sebaya karena dari hasil peneltian dan jurnal terdahulu belum secara konsisten dalam mempengaruhi perilaku menabung.

3. Penelitian selanjutnya diharapkan memperbanyak sampel penelitian, tidak hanya 3 Univeritas yang ada di Purwokerto saja namun bisa lebih agar semakin mengetahui karakteristik suatu populasi dari banyaknya sampel yang mewakili populasi tersebut secara keseluruhan. Atau peneliti bisa mengubah objek penelitiannya.

4. Bagi para mahasiswa agar memiliki pengetahuan yang lengkap di bidang personal financial yang sangat berguna dalam kehidupan sehari-hari. Dan sangat penting mahasiswa untuk mengembangkan kebiasaan dan perilaku keuangan yang positif seperti membuat anggaran dan mencatat pengeluaran, menabung secara rutin serta menyediakan dana untuk pengeluaran tidak terduga dan di masa yang akan datang.

\section{DAFTAR PUSTAKA}

Amilia, Suri (2018) Pengaruh Melek Finansial, Sosialisasi Orang Tua, dan Teman Sebaya Terhadap Perilaku Menabung Mahasiswa Bidik Misi Fakultas Ekonomi Universitas Samudra. Jurnal Samudra Ekonomika, Vol. 2,No. 2.

Ardiana, Meta (2016) Kontrol Diri, Pendidikan Pengelolaan Keuangan Keluarga, Pengetahuan Inklusi Keuangan Siswa Pengaruhnya Terhadap Perilaku Menabung Siswa Smk Se Kota Kediri. Jurnal Ekonomi Pendidikan dan Kewirausahaan.Vol.4.No. 1.

Arianti, Baiq Fitri (2018) The Influence Of Financial Literacy, Financial Behavior And Income On Investment Decision. Economics and Accounting Journal Vol.1, No.1.

Chalimah, Siti Nor at all (2019) The Saving Behavior of Public Vocational High School Students of Business and Management Program in Semarang. Journal of Economic Education 8 (1) 2019 : 22 - 29. e-ISSN 2502-4485

Chotimah, Chusnul (2015) Pengaruh Pendidikan Keuangan Di Keluarga, Sosial Ekonomi Orang Tua, Pengetahuan Keuangan, Kecerdasan Spiritual, Dan Teman Sebaya Terhadap Manajemen Keuangan Pribadi Mahasiswa S1 Pendidikan Akuntansi Fakultas Ekonomi Universitas Negeri Surabaya. Jurnal Pendidikan Akuntansi Vol 3, No 2

Dewi, Nurita, dkk (2017). Pengaruh Lingkungan Keluarga, Teman Sebaya, Pengendalian Diri dan Literasi Keuangan Terhadap Perilaku Konsumtif Mahasiswa. Journal of Economic Education.Vol.6. No.1. Hal: 29 - 35.

Ghozali, Imam. 2018. Aplikasi Analisis Multivariate dengan Program IBM SPSS 25. Semarang: Badan Peneliti Universitas Diponegoro.

Keynes, J. M. 1991. Teori Umum Mengenai Kesempatan Kerja, Bunga dan Uang. Yogyakarta: Gajah Mada UniversityPress

Lee, Jae Min dan Sherman D. Hanna. Savings Goals and Saving Behavior From a Perspective of Maslow's Hierarchy of Needs. Journal of Financial Counseling and Planning. Volume 26, Issue 2 2015, 129-147. https://doi.org/10.2307/40471184. 
Lestari, Dwi (2017) Pengaruh Literasi Keuangan Terhadap Perilaku Menabung (Studi Pada Siswa Sma Di Kota Bandung). In Search - Informatic, Science, Entrepreneur, Applied Art, Research, Humanism. Vol.16 No.2. E- Issn 25803239.

Marwati, Resti Desi. Faktor-faktor yang mempengaruhi perilaku menabung mahasiswa S1 Fakultas Ekonomii Universitas Negeri Yogyakarta. Jurnal Pendidikan Ekonomi. Volume 7, Nomor 5, Tahun 2018.

Nindya, Beta Ubaya dan Supramono. Perilaku menabung rumah tangga di program pembinaan kesejahteraan keluarga berbasis minat. Jurnal Ekonomi dan Bisnis. Volume 21 No. 1 April 2018, 43 - 58.

Putra, Bima Harya (2018) Pengaruh Sosialisasi Keuangan Keluarga Terhadap Perilaku Menabung Mahasiswa. Jurnal Pendidikan Ekonomi, Manajemen Dan Keuangan.Vol. 2 No. 2.

Putri, Tunggal Purnama (2018) Pengaruh Kontrol Diri, Literasi Keuangan, Dan Inklusi Keuangan Terhadap Perilaku Menabung. Jurnal Pendidikan Akuntansi. Volume 6 Nomor 3 Tahun 2018, 323-330.

Sirine, Hani dan Utami, Dwi Setiyani. Faktor-faktor yang mempengaruhi perilaku menabung dikalangan mahasiswa. Jurnal Ekonomi dan Bisnis. Volume 19 No. 1, April 2016.

Sugiyono. 2015. Metode Penelitian Kuantitatif, Kualitatif, dan R\&D. Bandung: CV Alfabeta.

Sujarweni, V. Wiratna.2016.Kupas Tuntas Penelitian Akuntansi Dengan SPPSS. Yogyakarta: Pustaka baru press.

Sukmawati, Dian (2016). Pengaruh Prestasi Belajar, Dukungan Sosial Keluarga Dan Teman Sebaya Terhadap Literasi Keuangan Siswa. Jurnal Ekonomi Pendidikan Dan Kewirausahaan.Vol.4.No.1.

Thung, C. M, dkk. 2012. Determinants Of Saving Behaviour Among The University Students In Malaysia. Malaysia: Faculty Of Business And Finance, Department Of Commerce And Accountancy, universiti Tunku Abdul Rahman.

Ulfatun, Titik, dkk (2016). Analisis Tingkat Literasi Keuangan Mahasiswa Fakultas Ekonomi Universitas Negeri Yogyakarta Tahun Angkatan 2012-2014.PELITA. Vol.XI. No.2.

Ulfi, Dina Shofa, dkk (2017) Hubungan Literasi Keuangan dan Perilaku Teman Sebaya Terhadap Kebiasaan Menabung Siswa Kelas XI SMA X Tahun 2017. Jurnal "Tata Arta" UNS, Vol. 3, No. 1, hlm 12-21

Wahana, A. 2014. Analisis Faktor-Faktor Yang Mempengaruhi Perilaku Mahasiswa Dalam Menabung (Studi Kasus Mahasiswa S1 FEB Undip Tembalang). Semarang: Fakultas Ekonomi dan Bisnis, Universitas Diponegoro. 